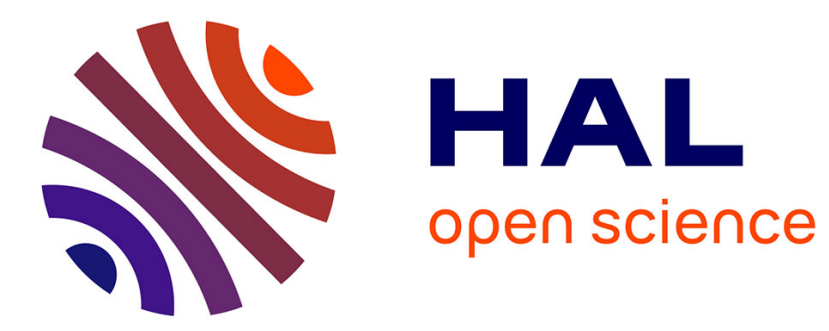

\title{
Fall-experiments on Merapi basaltic andesite and constraints on the generation of pyroclastic surges
}

L. M. Schwarzkopf, O. Spieler, B. Scheu, D. B. Dingwell

\section{To cite this version:}

L. M. Schwarzkopf, O. Spieler, B. Scheu, D. B. Dingwell. Fall-experiments on Merapi basaltic andesite and constraints on the generation of pyroclastic surges. eEarth, 2007, 2 (1), pp.1-5. hal-00298230

\section{HAL Id: hal-00298230 \\ https://hal.science/hal-00298230}

Submitted on 4 Jan 2007

HAL is a multi-disciplinary open access archive for the deposit and dissemination of scientific research documents, whether they are published or not. The documents may come from teaching and research institutions in France or abroad, or from public or private research centers.
L'archive ouverte pluridisciplinaire HAL, est destinée au dépôt et à la diffusion de documents scientifiques de niveau recherche, publiés ou non, émanant des établissements d'enseignement et de recherche français ou étrangers, des laboratoires publics ou privés. 


\title{
Fall-experiments on Merapi basaltic andesite and constraints on the generation of pyroclastic surges
}

\author{
L. M. Schwarzkopf ${ }^{1,2}$, O. Spieler ${ }^{1}$, B. Scheu ${ }^{1}$, and D. B. Dingwell ${ }^{1}$ \\ ${ }^{1}$ Earth \& Environmental Sciences, Ludwig-Maximilians-Universität München, Theresienstr. 41/III, 80333 München, \\ Germany \\ ${ }^{2}$ GeoDocCon, Unterpferdt 8, 95176 Konradsreuth, Germany
}

Received: 23 May 2006 - Published in eEarth Discuss.: 14 July 2006

Revised: 14 November 2006 - Accepted: 29 November 2006 - Published: 4 January 2007

\begin{abstract}
We have performed fall-experiments with basaltic andesite rock samples from Merapi volcano, using an apparatus designed to analyze samples heated up to $850^{\circ} \mathrm{C}$. Relative pressure changes during impact and fragmentation of the samples were measured by a pressure transducer. From $200^{\circ} \mathrm{C}$, dynamic pressure waves were formed on impact and fragmentation. Peak and duration of the pressure signal, and degree of fragmentation were found to strongly increase with increasing temperature of rock samples. The pressure waves are most likely generated by sudden heating of air forcing it to expand. We propose that the observed pressure changes are analogues to pyroclastic surges that may be generated on impact and fragmentation of large blocks during passage of a pyroclastic flow over a steep cliff. We infer that rock temperatures of ca. $400^{\circ} \mathrm{C}$ are sufficient for this process to occur, a temperature common in pyroclastic flows even in distal reaches.
\end{abstract}

\section{Introduction}

Pyroclastic surges, hot and gas-rich high-speed particle flows, are probably the largest hazards during volcanic eruptions. In general, surges are generated as either 1) sourcerelated lateral blast-surges, by flank (e.g. Kieffer, 1981) or lava dome collapses (e.g. Fink and Kieffer, 1993), or 2) as surges directly associated with a pyroclastic flow. In the latter case, surges are generated from the flow itself, by either entrainment of ambient air at the flow front (e.g. Sparks, 1978) or interaction between the flow surface and the air (Denlinger, 1987).

Flow-related surges can also be formed at breaks in slope, e.g. by detachment of the ash-cloud component (Bourdier and Abdurachman, 2001). Hoblitt (1986) and Calder et

Correspondence to: L. M. Schwarzkopf

(lothar_schwarzkopf@yahoo.de) al. (1997) discuss ash cloud generation at breaks in slope for Mount St. Helens, and Yamamoto et al. (1993) describe an expanding eruption cloud from a block-and-ash flow cascading down a $70 \mathrm{~m}$ high waterfall at Unzen. Expanding ash clouds at sudden breaks in slopes indicate intensified production of fines and thus fragmentation, and Schwarzkopf et al. (1998) postulate surge generation triggered by sudden and strongly intensified fragmentation at cliffs in the flow path of block-and-ash flows at Merapi. Schwarzkopf (2001) and Schwarzkopf et al. (2006) ${ }^{1}$ show that this fragmentation event was accompanied by degassing of matrix ashes and a discharge of fines that propagated downstream in front of the parental flow and deposited ground surge-like layers. Although degassing was evidenced by volatile contents of ash samples, it is unlikely to be the sole factor in the generation of cliff-triggered surges, since the Merapi dome lavas are already largely outgased and the closed porosity of the Merapi andesites is commonly less than $1 \%$ (Spieler, 2001). This leaves unclear the processes by which a surge could be generated on impact and disintegration of large blocks transported in pyroclastic flows.

In recent years, significant experimental work has been performed on the fragmentation of highly viscous volcanic rocks by rapid decompression (e.g. Alidibirov and Dingwell, 1996; Spieler et al., 2003). In contrast, impact fragmentation has been neglected in the volcanological literature so far. This is despite the fact that formation of fine particles by abrasion and fragmentation of hot pyroclasts by collisions is a poorly constrained process yet that may exert a significant control on the generation and emplacement of gas/particle mixtures in general. Experiments on impact processes were performed in the planetary sciences (e.g. Pier-

\footnotetext{
${ }^{1}$ Schwarzkopf, L. M., Schmincke, H.-U., and Troll, V. R.: Clifftriggered surge generation: evidence from the 1994 block-and-ash flows of Merapi volcano, Central Java, Indonesia, Bulletin of Volcanology, submitted, 2007.
} 


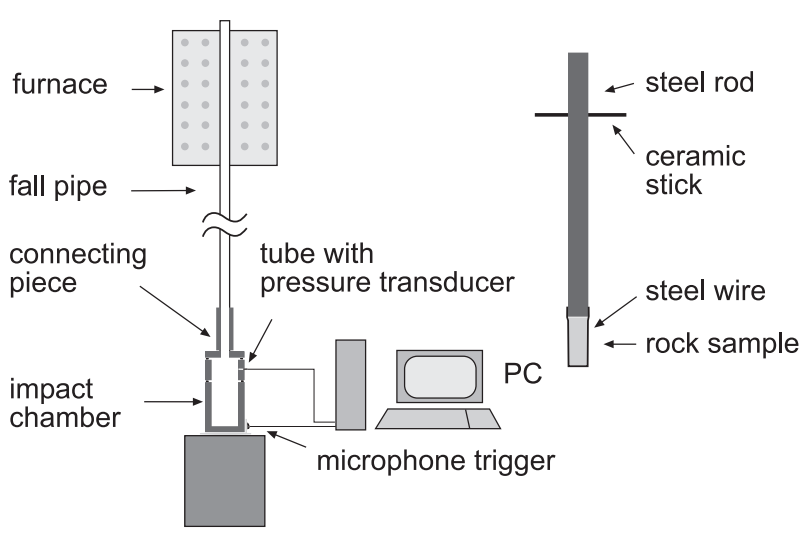

Fig. 1. Sketch of the experimental apparatus and measuring equipment, details of sample/fall weight given on the right side.

azzo and Melosh, 2000), wear research (e.g. Clark and Wong, 1995 ) and industrial granular matter research (e.g. Salman et al., 2002). Many of theses studies used high particle velocities (e.g. Durda and Flynn, 1999: $5 \mathrm{~km} \mathrm{~s}^{-1}$ ) or materials like ice (e.g. Kato et al., 1995) that are not relevant for pyroclastic flows, but some present results that may be transferable. Salman et al. (2002), for instance, shot non-heated spherical aluminium oxide particles with velocities between 5 and $28 \mathrm{~ms}^{-1}$ against a target. They showed that decreasing the impact velocity, impact angle and particle size decreased the fragmentation rate.

Due to the lack of low-velocity single particle impact experiments with heated samples that are applicable to pyroclastic flows that rush over a sudden break in slope, we designed a simple low-cost experimental set-up. We performed fall-experiments with natural Merapi rock samples and analyzed the pressure signals during the experiments and the grain-sizes of the resulting fragments, to better constrain the processes occurring during the impact of hot volcanic material. This paper reports the experimental set-up, results and their implications.

\section{Methods}

\subsection{Experimental set-up and procedure}

The experimental apparatus consists of a fall-acceleration section and an impact section (Fig. 1). The acceleration part is a vertical steel pipe (length $=300 \mathrm{~cm}$, internal diameter $=26 \mathrm{~mm}$ ). The steel pipe is adapted to the impact section by a steel connecting piece. The impact chamber consists of a steel connection tube with an uptake for a pressure transducer (length $=5 \mathrm{~cm}$, internal diameter $=62 \mathrm{~mm}$ ) and a basal steel tank (length $=15.5 \mathrm{~cm}$, internal diameter $=62 \mathrm{~mm}$ ). The volume of the impact section is $\sim 592 \mathrm{~cm}^{3}$. Samples were attached below a steel rod to add weight (length $=342 \mathrm{~mm}$, diameter $=24 \mathrm{~mm}$, weight $=1211.5 \mathrm{~g}$; Fig. 1 , right side). The additional fall weight is taken to simulate higher fall heights, to increase fragmentation, and to minimize effects of not precisely perpendicular impacts. We used simple steel wire (0.2 $\mathrm{mm}$ thick, thinner copper wires did not stand the high temperatures) to attach the samples to a drill-hole in the rod, since high-temperature cement was not suitable without using a sample holder, which was rejected to allow fragmentation of the total sample and to avoid potential shear fractures. Sample and rod are located inside the top part of the acceleration pipe using a ceramic stick that was inserted through a drill-hole in the upper part of the rod. The ceramic stick lies on the pipe walls, providing a constant fall-height for all experiments. Experiments were started by pulling the ceramic stick out by hand; sample and rod are accelerated by gravity only. The steel pipe is rigidly connected to a steel frame aside and the impact chamber is coupled to a massive steel cylinder using a thin layer of Silly Putty. The single parts of the impact section are fixed together by screws, with rubber sealings between the parts. A series of tests showed that internal and external vibrations disturbing the pressure measurements are successfully avoided by these simple means. The total fall height of the apparatus sums up to $3.2 \mathrm{~m}$, providing impact speeds of $\sim 7.6 \mathrm{~m} \mathrm{~s}^{-1}$, as measured using an optical sensor. Samples can be heated up to maximum $850^{\circ} \mathrm{C}$ by an external high-temperature furnace installed at the top of the acceleration pipe. Samples were heated for $15 \mathrm{~min}$., which was sufficient to provide the desired temperature as measured at the top of the sample below the steel rod. The relative pressure changes were measured by a piezoresistive pressure transducer (Kistler K 6421, Germany) at a sampling rate of $30 \mathrm{kHz}$, located in a drill-hole in the upper part of the basal steel tank. Data retrieval is controlled by a microphone trigger at the impact chamber that is released by the impact of the sample.

After each experiment the fragments were sampled from the impact chamber. Samples were wet-sieved by hand to avoid mechanical damage, in $1 \phi$ intervals from $2 \phi$ to $4 \phi$ ( $>4 \mathrm{~mm}$ to $<63$ micron; $\phi=-\log _{2} \mathrm{~d}$ where $\mathrm{d}=$ diameter in $\mathrm{mm}$ ), providing an error $<5 \%$ for our grain-size analyses. Median diameter $\left(\mathrm{Md}_{\phi}=\phi_{50}\right)$, mean diameter $\left(\mathrm{M}_{\phi}=\left(\phi_{16}+\phi_{84}\right) / 2\right)$ and sorting coefficient $\left(\sigma_{\phi}=\left(\phi_{84}-\phi_{16}\right) / 2\right)$ were determined from cumulative curves. To obtain the $\phi_{16}$ percentile, the cumulative curves were extrapolated.

\subsection{Experimental materials}

We use cylindrical samples (length $=60 \mathrm{~mm}$, diameter $=$ $22 \mathrm{~mm}$ ) of the 1998 Merapi block-and-ash flow deposits. Samples were of the most common rock type at recent Merapi deposits, a porphyritic, incipiently to poorly vesicular basaltic andesite (Gertisser, 2001; Schwarzkopf, 2001). The closed porosity of Merapi andesites is commonly less than $1 \%$ (Spieler, 2001), the open porosity of the main rock type between 5 and 40 vol.\% (Schwarzkopf, 2001). Merapi 


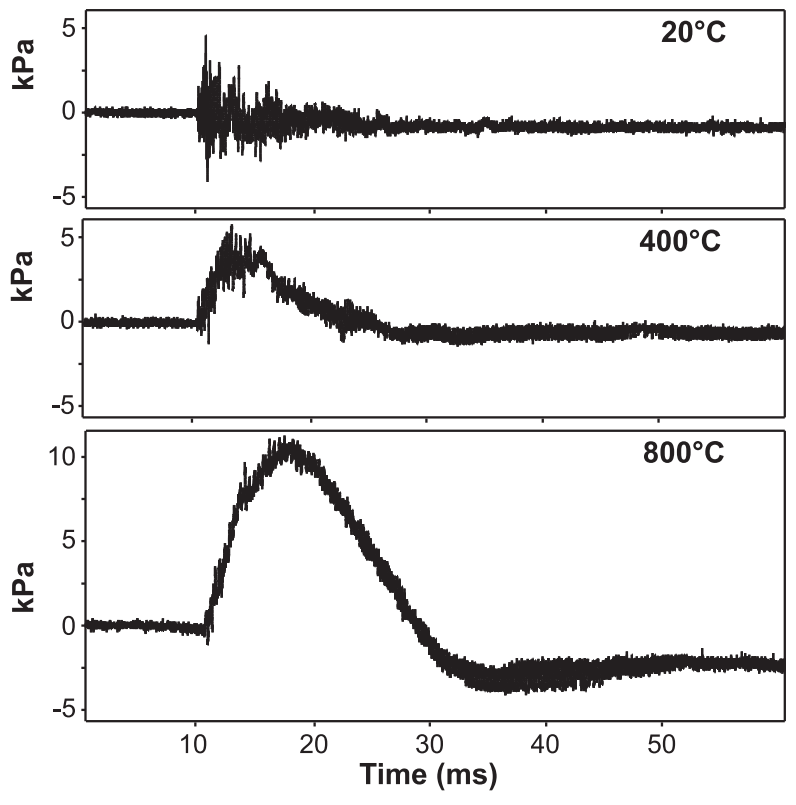

Fig. 2. Pressure data $(\mathrm{kPa})$ from a pressure transducer located at the top of the impact section versus time (ms). Graphs show the pressure data from reprentative experiments at $20^{\circ}, 400^{\circ}$ and $800^{\circ} \mathrm{C}$. Note sharply rising dynamic pressure waves occuring at higher temperatures.

andesites are generally highly porphyritic with phenocryst contents up to $60 \mathrm{vol} . \%$. Details of the petrology of recent Merapi rocks are e.g. given by Andreastuti (1999), Camus et al. (2000), Gertisser (2001) and Gertisser and Keller (2003). Densities of the samples were $\sim 2.75 \mathrm{~kg} \mathrm{~m}^{-3}$ (measured using an AccuPyc 1330 from Micromeritics, USA), and weights were $\sim 53 \mathrm{~g}$. In this study, we used only poorly vesicular samples with porosities between 5 and 15 vol.\%.

\section{Results}

We performed our experiments in $200^{\circ} \mathrm{C}$ steps, starting at room temperature up to $800^{\circ} \mathrm{C}$. Each set consisted typically of 3 to 5 runs. Additional experiments for video observations were performed up to maximum $850^{\circ} \mathrm{C}$.

\subsection{Pressure changes}

The data were originally measured in $\mathrm{V}$ and then calculated in $\mathrm{kPa}\left(1 \mathrm{~V}=8 \times 10^{-2} \mathrm{MPa}\right.$ in our set-up). The diagrams in Fig. 2 show representative pressure measurements during our impact experiments. At $20^{\circ} \mathrm{C}$, the signal is a fast decaying wave that is similar in quality and peak to the signals from test runs using only the steel rod without sample. Starting at $200^{\circ} \mathrm{C}$, the pressure signal becomes pulse-like, and at $400^{\circ} \mathrm{C}$, the signal clearly forms a dynamic pressure wave with a sharp rise. With higher temperatures, the pressure waves be-

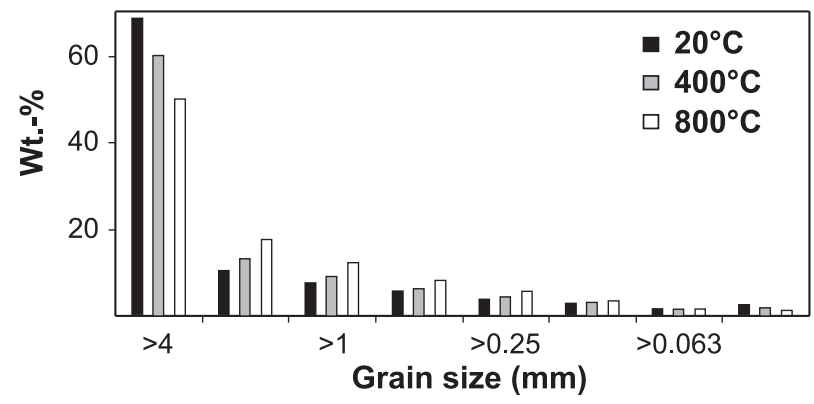

Fig. 3. Grain-size distributions of the fragments resulting from representative runs. Note significant decrease of the coarse and increase of the fine fractions strongly depending on sample temperatures.

Table 1. Grain-size characteristics of some representative experimental fragments.

\begin{tabular}{lccc}
\hline Exp.-No. & IMS-27 & IMS-30 & IMS-36 \\
\hline Temperature & $20^{\circ} \mathrm{C}$ & $400^{\circ} \mathrm{C}$ & $800^{\circ} \mathrm{C}$ \\
Mean & -2.24 & -1.88 & -1.8 \\
$\mathrm{M}_{\phi}=\left(\phi_{16}+\phi_{84}\right) / 2$ & & & \\
Median & -3.13 & -3.08 & -3 \\
$\mathrm{Md}_{\phi}=\phi_{50}$ & & & \\
Sorting coefficient & 1.15 & 1.49 & 1.54 \\
$\sigma_{\phi}=\left(\phi_{84}-\phi_{18}\right) / 2$ & & & \\
\hline
\end{tabular}

come more and more distinct, and stronger, as deduced from the peak height, and the durations of the signals increase.

The signal peaks range from 3.2 to $4.8 \mathrm{kPa}$ at $20^{\circ} \mathrm{C}$, from 6.4 to $9.6 \mathrm{kPa}$ at $400^{\circ} \mathrm{C}$, and from 11.2 to $12.0 \mathrm{kPa}$ at $800^{\circ} \mathrm{C}$, with an absolute maximum of $24.0 \mathrm{kPa}$ in one $800^{\circ} \mathrm{C}$ run. The rise times are in the order of several milliseconds ( 3 to $8 \mathrm{~ms}$ ), the total durations of the waves in the order of tens of ms.

\subsection{Grain-size of the fragments}

The experimental fragments show wide grain-size distributions. Grain-size distributions are unimodal, with a prominent peak of particles larger than $4 \mathrm{~mm}$ in size (Fig. 3). The mean diameter $\mathrm{M}_{\phi}$ ranges from -2.24 to $-1.8 \phi$, the median diameter $\mathrm{Md}_{\phi}$ from -3.13 to $-3.00 \phi$, and the sorting coefficient $\sigma_{\phi}$ from 1,15 to $1.54 \phi$ (Table 1 ).

These characteristics vary in clear dependence on the sample temperature, increasing temperature decreases the resulting grain-sizes and reduces the quality of sorting. For instance, the content of particles larger than $4 \mathrm{~mm}$ in size decreases from ca. 70 to $50 \mathrm{wt} . \%$ with increasing temperatures that of the particles between 1 and $2 \mathrm{~mm}$ increases from 7.1 to $12.4 \mathrm{wt} . \%$, and the content of 125 to 250 micron particles increases from 2.4 to $3.5 \mathrm{wt} . \%$. The contents of particles 


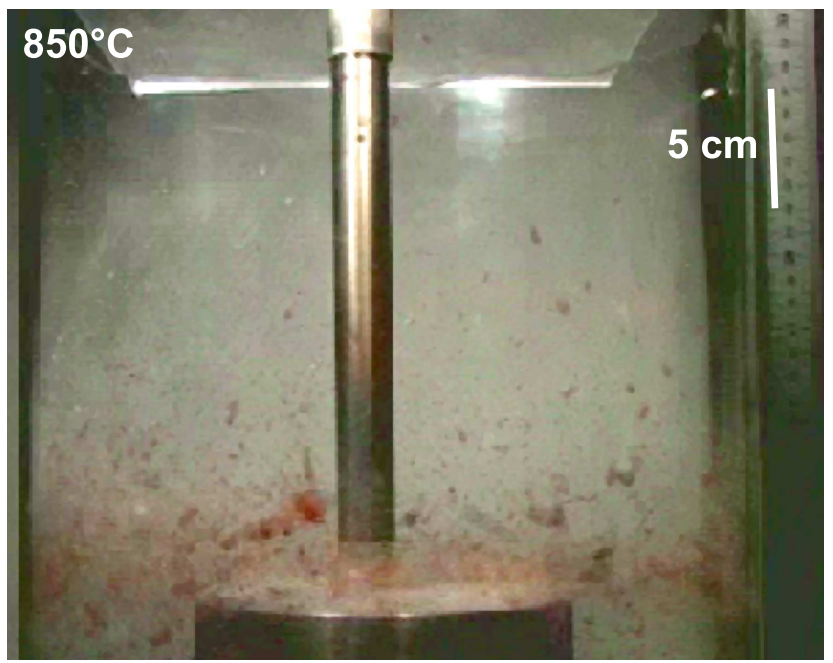

Fig. 4. Picture from a video of one $850^{\circ} \mathrm{C}$ impact experiment, showing total fragmentation of the rock sample. Note strongly horizontal directed movement of fine fragments (http://www.electronic-earth. net/2/1/2007/ee-2-1-2007-supplement.zip).

smaller than 125 micron do not vary significantly, possibly due to a loss of fines during the experiments.

\subsection{Video observations}

We also performed a series of experiments in which we used a massive steel cylinder as impact target that was surrounded by a simple Plexiglas tube. Videos of these experiments were taken with an ordinary digital video camera at 30 frames per second (Fig. 4), and a high-speed camera with a resolution of $256 \times 256$ pixels at a frame rate of $0.82 \mathrm{~ms}$ (http://www.electronic-earth.net/2/1/2007/ ee-2-1-2007-supplement.zip). We observed increasing fragmentation with higher temperatures and a plastering of very fine fragments at the Plexiglas tube, leaving a horizontal ringlike deposit. This deposit thickens with higher temperatures. From the plastering and the video observations we infer that the horizontally moving particle current generated on impact is more intense at higher temperatures. Due to the strong loss of material in the open system, we did not analyze the samples, and observations are only to be taken qualitatively.

\section{Discussion}

Our impact experiments with cold and heated natural rock samples show 1) dynamic pressure waves are generated on impact and fragmentation, and 2) strength of pressure waves and fragmentation of the samples significantly increase with higher temperatures.

The pressure waves are not formed by simple displace or compression of air in the impact chamber. Data of the whole experiment durations show a slight and constant increase in the pressure signal. This signal is totally different in rising time and form, clearly associated with compression of the air inside the impact chamber below the falling steel rod and sample, and thus not caused by the impact and fragmentation processes. The compression signal is more or less constant in all experiments. From our video observations of open system experiments we infer that the used impact chamber geometry has no significant influence on the generation of pressure waves. The pressure waves are most likely generated by the sudden heating of air forcing it to expand. The effectiveness of this process depends on the sample temperature that controls the absolute rise in temperature, and on the degree of fragmentation that controls the time in which the air is heated. This explains the rather drastic dependence of the strength of the observed pressure waves on the rock sample temperatures.

Dynamic pressures of particle-free atmospheric winds are $0.1 \mathrm{kPa}$ at speeds of $33 \mathrm{~km} / \mathrm{h}$ and $1.0 \mathrm{kPa}$ at $105 \mathrm{~km} / \mathrm{h}$ (Valentine and Wohletz, 1989). For reasonable particle concentrations and velocities, dynamic pressures of pyroclastic density currents range from 0.1 to $10^{4} \mathrm{kPa}$ (Valentine, 1998). Sparks et al. (2002) calculated $9 \times 10^{4}$ to $1.08 \times 10^{5} \mathrm{~Pa}$ and $9 \times 10^{4}$ to $4 \times 10^{4} \mathrm{~Pa}$ for pyroclastic density currents at Soufrière Hills volcano, for inclusion or non-inclusion of fallout from the current respectively. Nunziante et al. (2003) calculate 1 to $5 \mathrm{kPa}$ for pyroclastic density currents of the A.D. 79 Vesuvius eruption. Dynamic pressures of the currents strongly vary during transport (Valentine and Wohletz, 1989; Sparks et al., 2002).

The pressure wave peaks in our experiments range from ca. 3 to $12.0 \mathrm{kPa}$ (absolute maximum of $24.0 \mathrm{kPa}$ in one $800^{\circ} \mathrm{C}$ run). Considering the small sample size, the total weight of ca. $1.26 \mathrm{~kg}$ of sample and steel rod and the fall height of only $\sim 3 \mathrm{~m}$, it seems plausible to infer the generation of severe pressure waves on impact and fragmentation of numerous m-sized blocks as in the case of a pyroclastic flow rushing down a cliff several $10 \mathrm{~s}$ of $\mathrm{m}$ high. Degassing is not the main factor for generation of dynamic pressure waves on impact and fragmentation, but may be a substantial aid, especially involving rocks richer in volatiles than already largely outgased Merapi dome andesites. Rock temperatures of ca. $400^{\circ} \mathrm{C}$ are sufficient to generate dynamic pressure waves. Such rock temperatures are common in pyroclastic flows, even far away from the flow sources. Assuming that pyroclastic surges can be generated by these processes, areas around active volcanoes that appeared to be safe so far may be endangered by pyroclastic surges in a manner not yet incorporated in risk analyses.

Acknowledgements. This study was supported by the Deutsche Forschungsgemeinschaft (Di 431/8-4). We thank U. Küppers and S. Müller for sample preparation assistance, and W. Poppe for technical assistance in building the experimental advice. L. M. Schwarzkopf thanks the Direktorat Vulkanologi, Yogyakarta, for logistic assistance, and V. Troll for help during sample collection in the field. 
Edited by: B. Wuming

\section{References}

Alidibirov, M. and Dingwell, D. B.: Magma fragmentation by rapid decompression, Nature, 380, 46-148, 1996.

Andreastuti, S. D.: Stratigraphy and geochemistry of Merapi Volcano, Central Java, Indonesia: implication for assessment of volcanic hazards, PhD thesis, Univ. Auckland, New Zealand, 1999.

Bourdier, J.-L. and Abdurachman, E. K.: Decoupling of smallvolume pyroclastic flows and related hazards at Merapi volcano, Indonesia, Bull. Volcanol., 63, 309-325, 2001.

Calder, E. S., Sparks, R. S. J., and Woods, A. W.: Dynamics of coignimbrite plumes generated from pyroclastic flows of Mount St. Helens (7 August 1980), Bull. Volcanol., 58, 432-440, 1997.

Camus, G., Gourgaud, A., Mossand-Berthommier, P.-C., and Vincent, P. M.: Merapi (Central Java, Indonesia): an outline of the structural and magmatological evolution, with a special emphasis to the major pyroclastic events, J. Volcanol. Geotherm. Res., 100, 139-163, 2000.

Clark, H. McI. and Wong, K. K.: Impact angle, particle energy and mass loss in erosion by dilute slurries, Wear, 186-187, 454-464, 1995.

Denlinger, R. P.: A model for the generation of ash clouds by pyroclastic flows, with application to the 1980 eruptions at Mount St. Helens, Washington, J. Geophys. Res., 92, 10 284-10 298, 1987.

Durda, D. D. and Flynn, G. J.: Experimental study of the impact disruption of a porous, inhomogenous target, Icarus, 142, 46-55, 1999.

Fink, J. H. and Kieffer, S. W.: Estimate of pyroclastic flow velocities from explosive decompression of lava domes, Nature, 363, 612-615, 1993.

Gertisser, R.: Gunung Merapi (Java, Indonesien): Eruptionsgeschichte und magmatische Evolution eines HochrisikoVulkans, PhD thesis, 382 pp., Univ. Freiburg, Germany, 2001.

Gertisser, R. and Keller, J.: Temporal variations in magma composition at Merapi Volcano (Central Java, Indonesia): magmatic cycles during the past 2000 years of explosive activity, J. Volcanol. Geotherm. Res., 123, 1-23, 2003.

Hoblitt, R. P.: Observations of the eruptions of July 22 and August 7, 1980, at Mount St. Helens, Washington, 44 pp., U.S.G.S. Prof. Paper 1335, Univ. of Washington Press, Washington, 1986.

Kato, M., Iijima, Y., Arakawa, M., Okimura, Y., Fujimura, A., Maeno, N., and Mizutani, H.: Ice-on-ice impact experiments, Icarus, 113, 423-441, 1995.
Kieffer, S. W.: Fluid dynamics of the May 18 blast at Mount St. Helens, in: The 1980 eruptions of Mount St. Helens, Washington, edited by: Lipman, P. W. and Mullineaux, D. R., pp. 545-570, U.S.G.S. Prof. Paper 1250, Univ. of Washington Press, Washington, 1981.

Nunziante, L., Fraldi, M., Lirer, L., Petrosino, P., Scotellaro, S., and Cicirelli, C.: Risk assessment of the impact of pyroclastic currents on the towns located around Vesuvio: a non-linear structural inverse analysis, Bull. Volcanol., 65, 547-561, 2003.

Pierazzo, E. and Melosh, H. J.: Understanding oblique impacts from experiments, observations, and modelling, Ann. Rev. Earth Planet. Sci., 28, 141-167, 2000.

Salman, A. D., Biggs, V., Fu, J., Angyal, I., Szabó, M., and Hounslow, M. J.: An experimental investigation of particle fragmentation using single particle impact studies, Powder Technology, 128, 36-46, 2002.

Schwarzkopf, L. M.: The 1994 and 1998 block-and-ash flow deposits at Merapi Volcano, Central Java, Indonesia: implications for emplacement mechanisms and hazard mitigation, $\mathrm{PhD}$ thesis, 94 pp., Christian-Albrechts-Univ. Kiel, Germany, 2001.

Schwarzkopf, L., Schmincke, H.-U., and Freundt, A.: Eruptive mechanisms of Merapi volcano during the 20th century with emphasis on structure and transport of the block-and-ash flow of 1994, DGG-Mitteilungen, Sd. III/1998, p. 21-24, 1998.

Sparks, R. S. J.: Gas release rates from pyroclastic flows: an assessment of the role of fluidisation in their emplacement, Bulletin of Volcanology, 41, 1-9, 1978.

Sparks, R. S. J., Barclay, J., E. Calder, S., Herd, R. A., Komorowski, J.-C., Luckett, R., Norton, G. E., Ritchie, L. J., Voight, B., and Woods, A. W.: Generation of a debris avalanche and violent pyroclastic density current on 26 December (Boxing Day) 1997 at Soufrière Hills Volcano, Montserrat, in: The eruption of Soufrière Hills Volcano, Montserrat, from 1995 to 1999, edited by: Druitt, T. H. and Kokelaar, B. P., pp. 231-262, Geol. Soc. Mem. 21, London, 2002.

Spieler, O.: Die Fragmentierung hochviskoser Magmen: Experimenteller Aufbau und Analysetechniken, $\mathrm{PhD}$ thesis, $135 \mathrm{pp}$. Ludwig-Maximilians-Univ. München, Germany, 2001.

Spieler, O., Alidibirov, A., and Dingwell, D. B.: Grain-size characteristics of experimental pyroclasts of 1980 Mount St. Helens cryptodome dacite: effects of pressure drop and temperature, Bull. Volcanol., 65, 90-104, 2003.

Valentine, G. A.: Damage to structures by pyroclastic flows and surges, inferred from nuclear weapons effects, J. Volcanol. Geotherm. Res., 87, 117-140, 1998.

Valentine, G. A. and Wohletz, K. H.: Environmental hazards of pyroclastic flows determined by numerical models, Geology, 17, 641-644, 1989.

Yamamoto, T., Takarada, S., and Suto, S.: Pyroclastic flows from the 1991 eruption of Unzen volcano, Japan, Bull. Volcanol., 55, 166-175, 1993. 